\title{
Elevated expression and altered processing of fibulin-I protein in human breast cancer
}

\author{
LM Greene', WO Twal' ${ }^{2}$ MJ Duffy ${ }^{3}$, EW McDermott ${ }^{4}$, AD Hill ${ }^{4}$, NJ O'Higgins ${ }^{4}$, AH McCann ${ }^{5,6}$, PA Dervan ${ }^{5,6}$, \\ WS Argraves ${ }^{2}$ and WM Gallagher*,I
}

'Department of Pharmacology, Conway Institute of Biomolecular and Biomedical Research, University College Dublin, Belfield, Dublin 4, Ireland; ${ }^{2}$ Department of Cell Biology and Anatomy, Medical University of South Carolina, 173 Ashley Avenue, Charleston, SC, USA; ${ }^{3}$ Department of Nuclear Medicine, St Vincent's University Hospital, Elm Park, Dublin 4, Ireland; ${ }^{4}$ Department of Surgery, St Vincent's University Hospital, Elm Park, Dublin 4, Ireland; ${ }^{5}$ Department of Pathology, Conway Institute of Biomolecular and Biomedical Research, University College Dublin, Belfield, Dublin 4, Ireland;

${ }^{6}$ Mater Hospital, Eccles Street, Dublin 7, Ireland

\begin{abstract}
The extracellular matrix protein fibulin-I suppresses the motility and invasiveness of a variety of tumour cell types in vitro as well as the growth of fibrosarcoma tumours in nude mice. In this study, fibulin-I protein expression in breast carcinoma specimens and normal breast tissue was evaluated immunohistologically. Fibulin-I protein expression was also semiquantitatively assessed by immunoblot analysis in a collection of normal breast tissues $(n=18)$, benign tumours $(n=5)$ and breast carcinomas $(n=39)$. In normal breast tissue, fibulin- I protein expression predominated in the ductal epithelium and underlying myoepithelium, with weaker staining evident in the loose connective surrounding the ducts. Examination of breast carcinomas revealed that the tumour cells also expressed fibulin-I protein. The level of mature fibulin-I polypeptide $(100 \mathrm{kDa})$ was higher in the breast carcinoma specimens as compared to normal breast tissue (Mann-Whitney $U$-test, $P=0.0005)$. In addition to the mature fibulin-I polypeptide, several smaller sized polypeptides of 55, 50 and $25 \mathrm{kDa}$ were detected using monoclonal antibodies reactive towards an epitope located at the $\mathrm{N}$-terminus of fibulin-I. The immunoreactive $50 \mathrm{kDa}$ polypeptide was detected more frequently in breast carcinoma specimens than in normal breast tissue $\left(\chi^{2}=17.22, P<0.000 \mathrm{I}\right)$. Furthermore, the ratio of the $50 \mathrm{kDa}$ fragment to the mature fibulin-I polypeptide correlated with the level of oestrogen receptor $\alpha$ (Spearman correlation coefficient, $r s=0.49, P<0.003, n=36$ ) and progesterone receptor ( $r=0.43, P=0.008, n=36$ ) expression in the tumour specimens. Taken together, these findings indicate that elevated expression and altered processing of fibulin- $I$ is associated with human breast cancer.

British Journal of Cancer (2003) 88, 87I-878. doi: I 0.1038/sj.bjc.6600802 www.bjcancer.com

(c) 2003 Cancer Research UK
\end{abstract}

Keywords: fibulin; breast cancer; extracellular matrix; proteolysis; oestrogen receptor

Fibulin-1 is an extracellular matrix and plasma protein that has been implicated as playing a role in tumour progression (Qing et al, 1997; Hayashido et al, 1998; Twal et al, 2001). Alternative splicing of fibulin-1 precursor results in four transcript variants, designated $\mathrm{A}-\mathrm{D}$, of which $\mathrm{C}$ and $\mathrm{D}$ are predominantly expressed (Tran et al, 1997). Overexpression of fibulin-1D in fibrosarcoma-derived cells has been shown to delay tumour formation in nude mice and suppress invasion into gels of reconstituted basement membrane extracts (Qing et al, 1997). Furthermore, human placenta-derived fibulin-1 protein has also been shown to inhibit cell adhesion, spreading and motility of a range of human tumour cell lines, including those originating from melanoma, epidermoid carcinoma and breast carcinoma (Twal et al, 2001). A recent study showed increased fibulin-1C:1D mRNA ratios in ovarian carcinomas (Moll et al, 2002). Additionally, fibulin-1C expression is induced by oestradiol in oestrogen receptor $\alpha(\mathrm{ER} \alpha)$-positive ovarian tumour cells (Clinton et al, 1996; Moll et al, 2002). These

*Correspondence: Dr WM Gallagher; E-mail: william.gallagher@ucd.ie Received 14 August 2002; revised 9 December 2002; accepted 12 December 2002 results suggest that the biological function of fibulin-1 during tumour progression may be variant-specific.

Despite there being substantial evidence for fibulin-1 having the ability to influence tumour cell behaviour, there is a very limited understanding of the expression of fibulin-1 protein in association with human cancers. Indeed, there are only two reports to date (both from the same research group) that document the expression of fibulin-1 in human cancer, specifically ovarian carcinoma (Roger et al, 1998; Moll et al, 2002). In this study, we evaluated fibulin-1 protein expression in human breast tumours. We also sought to correlate fibulin-1 expression levels with the oestrogen receptor status of the breast tumour specimens.

\section{MATERIALS AND METHODS}

\section{Handling of tumours}

The breast tissue samples used in this study were obtained from the Department of Surgery, St Vincent's University Hospital, Dublin and the Department of Pathology, Mater Private Hospital, Dublin. Patient characteristics, including histological details and steroid receptor status, are summarised in Table 1. ER $\alpha$ and 
Table I Patient and histological data associated with tumor specimens

\begin{tabular}{|c|c|}
\hline Characteristic & $n(\%)$ \\
\hline \multicolumn{2}{|l|}{ Patients } \\
\hline Total n & $62(100)$ \\
\hline Normals & $18(29)$ \\
\hline \multicolumn{2}{|l|}{ Benign tumours } \\
\hline Fibroadenomas & $4(6.5)$ \\
\hline Phylloides & $1(1.6)$ \\
\hline \multicolumn{2}{|l|}{ Breast Carcinomas } \\
\hline Primary tumours & $36(58.1)$ \\
\hline Lymph node metatastasis & $3(4.8)$ \\
\hline \multicolumn{2}{|l|}{ Carcinomas } \\
\hline \multicolumn{2}{|l|}{ Size $(\mathrm{cm})$} \\
\hline$\leqslant 2$ & $6(15.4)$ \\
\hline$>2$ & $30(76.9)$ \\
\hline Unknown & $3(7.7)$ \\
\hline \multicolumn{2}{|l|}{ Histological type } \\
\hline Ductal & $27(69.2)$ \\
\hline Lobular & $7(18)$ \\
\hline Unknown & $5(12.8)$ \\
\hline \multicolumn{2}{|l|}{ Grade } \\
\hline । & $2(5.1)$ \\
\hline 2 & $10(25.6)$ \\
\hline 3 & $20(51.3)$ \\
\hline Unknown & $7(18)$ \\
\hline \multicolumn{2}{|l|}{ Nodal status } \\
\hline Negative & $7(18)$ \\
\hline Positive & $27(69.2)$ \\
\hline Unknown & $5(12.8)$ \\
\hline \multicolumn{2}{|l|}{$E R \alpha$ status $^{\mathrm{a}}$} \\
\hline Positive & $20(51.3)$ \\
\hline Negative & $16(4 \mid)$ \\
\hline Unknown & $3(7.7)$ \\
\hline \multicolumn{2}{|l|}{$P R$ status $^{\mathrm{b}}$} \\
\hline Positive & $15(38.5)$ \\
\hline Negative & $21(53.8)$ \\
\hline Unknown & $3(7.7)$ \\
\hline
\end{tabular}

${ }^{\mathrm{a}} \mathrm{ER} \alpha=$ oestrogen receptor alpha. ${ }^{\mathrm{b}} \mathrm{PR}=$ progesterone receptor.

progesterone receptor (PR) status of the breast tumours was determined by cytosolic assays (Cullen et al, 2001). The cutoff point for $\mathrm{ER} \alpha$ and PR status was $200 \mathrm{fmol}^{-1}$. Normal breast tissue specimens were obtained from sites either remote from the primary tumour or from cosmetic reduction mammoplasties.

\section{Immunohistochemistry}

Tumour specimens were fixed in $3.7 \%$ paraformaldehyde for $24 \mathrm{~h}$, embedded in paraffin wax and sectioned at $5 \mu \mathrm{m}$ thickness. Sections were deparaffinised with xylene and graded ethanol, followed by rehydration with phosphate-buffered saline (PBS) at $\mathrm{pH}$ 7.3. Endogenous peroxidase activity was quenched by incubating the sections with $3 \%$ hydrogen peroxide in PBS for 10 min. Sections were subsequently washed with PBS and blocked by incubation with 5\% normal horse serum in PBS (blocking solution A) for $20 \mathrm{~min}$ at room temperature (RT). Sections were then incubated with the mouse antifibulin-1 monoclonal antibody (mAb) 3A11, diluted $1 / 500\left(3 \mu \mathrm{g} \mathrm{ml}^{-1}\right)$ in blocking solution $\mathrm{A}$, for $2 \mathrm{~h}$ at RT. After washing with PBS, immunoglobulin $\mathrm{G}(\operatorname{IgG})$ detection was performed with the Vectastain Elite ABC kit (Vector Laboratories, Peterborough, UK) according to the manufacturer's recommendations. Staining was then visualised using $0.05 \%$ 3,3-diaminobenzidine $/ 0.01 \%$ hydrogen peroxide (Vector Laboratories). Nuclei were counterstained using methyl green (Vector Laboratories). Sections were then dehydrated and mounted in distrene dibutylpthalate xylene. Immunostaining specificity was checked using an irrelevant mouse mAb (UPC10; Sigma, Dorset, UK) of the same immunoglobulin subclass (IgG2a) as the antifibulin-1 mAb.

\section{Immunoblot analysis}

Breast tissue specimens were rapidly frozen in liquid nitrogen and stored at $-80^{\circ} \mathrm{C}$. Tissue homogenisation was carried out using a Braun Micro Dismembrator (Braun, Melsungen, Germany. Twenty-five milligram of tissue powder was extracted by a brief vortex in $250 \mu$ l RIPA buffer ( $50 \mathrm{~mm}$ Tris, $150 \mathrm{~mm} \mathrm{NaCl} \mathrm{pH} \mathrm{7.4,} 1 \%$ NP-40, $0.5 \%$ deoxycholate, $0.1 \%$ sodium dodecyl sulphate (SDS), $10 \mathrm{~mm}$ EDTA, $2 \mathrm{~mm}$ phenylmethylsulphonyl fluoride (PMSF) and $5 \mathrm{~mm} N$-ethylmaleimide (NEM)) followed by incubation at $4{ }^{\circ} \mathrm{C}$ for $1 \mathrm{~h}$ on a rotisserie. All extracts were then centrifuged at $13000 \mathrm{~g}$ for $15 \mathrm{~min}$. Supernatants were removed and the protein content of the extracts determined using the bicinchoninic acid protein assay kit (Pierce Chemical, Rockford, IL, USA) with bovine serum albumin as the protein standard. Protein extracts were stored in aliquots at $-80^{\circ} \mathrm{C}$.

Forty microgram of protein was mixed with an equal volume of SDS sample buffer, separated on a $10 \%$ SDS/polyacrylamide gel and subsequently electroblotted onto a polyvinylidene difluoride (PVDF) membrane (Bio-Rad, Hercules, CA, USA). Electroblotted proteins were visualised via Ponceau Red staining. Human fibulin-1 protein, isolated from human placenta by immunoaffinity chromatography (Balbona et al, 1992), was used as a positive control for immunoblotting. Electroblotted membranes were blocked for $2 \mathrm{~h}$ at RT in Tris-buffered saline (TBS) (50 mM Tris, $150 \mathrm{~mm} \mathrm{NaCl} \mathrm{pH} \mathrm{7.6)} \mathrm{containing} 0.1 \%\left(\mathrm{vv}^{-1}\right)$ Tween-20 and $5 \%$ $\left(\mathrm{w} \mathrm{v}^{-1}\right)$ nonfat dried milk (blocking solution $\left.\mathrm{B}\right)$. The membranes were washed briefly in TBS $/ 0.1 \%$ Tween-20 and then probed overnight at $4{ }^{\circ} \mathrm{C}$ with mouse antifibulin-1 mAb $3 \mathrm{~A} 11$ diluted $1 / 1500\left(1 \mu \mathrm{g} \mathrm{ml}^{-1}\right)$ in $5 \%$ blocking solution B. Following $3 \times 10 \mathrm{~min}$ washes in TBS $/ 0.1 \%$ Tween-20, membranes were incubated with horseradish peroxidase-conjugated goat anti-mouse IgG (Promega, Madison, WI, USA) diluted $1 / 2500$ in $5 \%$ blocking solution for $30 \mathrm{~min}$ at RT. After washing, immunoreactive complexes were detected by enhanced chemiluminescence using ECL Plus (Amersham Pharmacia Biotech, England) and recorded by exposure to BioMax ML autoradiographic film (Eastman Kodak Company, Rochester, NY, USA).

The PR status of the human breast cancer cell lines was confirmed by immunoblot analysis. Probed membranes were stripped and reprobed overnight at $4^{\circ} \mathrm{C}$ with $1 \mu \mathrm{g} \mathrm{ml}^{-1}$ mouse anti-PR mAb (clone PR4-12) (Oncogene Research Products, Cambridge, UK). Following detection, blots were again stripped and reprobed for $1.5 \mathrm{~h}$ at $\mathrm{RT}$ with the panspecific mouse antiactin $\mathrm{mAb}$ (clone JLA20) (Oncogene), diluted $1 / 5000$ in 5\% blocking solution $\mathrm{B}$, to control for equal loading of protein. Bound antibodies were detected as above.

\section{Cells}

Three ER/PR-positive human breast cancer cell lines (MCF-7, T-47-D and BT-474) and three ER/PR-negative human breast cancer cell lines (MDA-MB-231, HS-578-T and SK-BR-3) were used in this study. All cell lines were obtained from the European Collection of Cell Cultures (http://www.ecacc.org/). MCF-7 cells were grown in minimal essential medium (MEM) (Sigma, Dorset, UK) supplemented with $1 \%$ nonessential amino acids (Sigma). T47-D and MDA-MB-231 cells were grown in Dulbecco's modified Eagle's medium (DMEM) (GIBCO BRL, Life Technologies, UK). HS-578-T cells were grown in DMEM supplemented with $10 \mu \mathrm{g} \mathrm{ml}^{-1}$ insulin (Sigma). BT-474 cells were grown in RPMI1640 (Sigma). SK-BR-3 cells were grown in McCoy's 5a medium modified (Sigma). All the above-mentioned cell culture medium 
types were supplemented with $10 \%$ foetal calf serum (FCS), $2 \mathrm{~mm}$ L-glutamine, penicillin $\left(100\right.$ units $\left.\mathrm{ml}^{-1}\right)$ and streptomycin $\left(100 \mu \mathrm{g} \mathrm{ml}^{-1}\right)$ (GIBCO). Cells were maintained at $37^{\circ} \mathrm{C}$ in $5 \% \mathrm{CO}_{2}$ at $100 \%$ humidity. At 5 to 7 day intervals, cells were passaged using trypsin-EDTA (GIBCO).

\section{Effect of oestrogen on fibulin-1 processing by cultured cells}

Steroids were depleted from heat-inactivated FCS with dextrancoated-activated charcoal (DCC) (Sigma) (Devleeschouwer et al, 1987). Cells were grown for 5 days in phenol red-free medium containing 10\% DCC-treated FCS. Cells were then washed with phenol red-free medium and treated for $48 \mathrm{~h}$ with either $10 \mathrm{nM}$ oestradiol, or ethanol vehicle in phenol red-free medium minus serum. After $48 \mathrm{~h}$, the conditioned culture medium (CCM) was removed and both PMSF and NEM added to 2 and $5 \mathrm{~mm}$ final concentration, respectively. Cell debris was removed by centrifugation. The supernatant was then concentrated using Centricon YM-30 filters (Millipore, Malborough, MA, USA) for $1 \mathrm{~h}$ at $3000 \mathrm{~g}$. The protein content of the concentrated CCM was determined as described above. The remaining cell layer was washed twice with ice-cold PBS and extracted using RIPA buffer supplemented with $10 \mathrm{~mm}$ EDTA. The extract was then centrifuged at $13000 \mathrm{~g}$ for $15 \mathrm{~min}$ at $4{ }^{\circ} \mathrm{C}$. The supernatant was removed and protein concentration of the extract determined. Forty microgram aliquots of protein were evaluated by immunoblot analysis as described above.

\section{Quantification and statistical analysis}

Radiographs from immunoblot experiments were scanned and densitometric analysis performed using a GDS 8000 system, together with Gel Works 1D analysis software (Ultra-Violet Products Ltd, Cambridge, England). Nonspecific background was subtracted and band intensity values derived. Comparisons between unpaired groups were performed using the nonparametric Mann-Whitney $U$-test. Associations between either fibulin-1 expression or processing and clinicopathological parameters were examined using the Spearman rank correlation test or with dichotomised variables using the $\chi^{2}$ test of independence. All reported $P$-values refer to a two-sided test of significance. $P$-values $\leqslant 0.05$ were considered to be significant.

\section{RESULTS}

\section{Fibulin-1 protein expression in human breast cancers and normal breast tissue}

Fibulin-1 protein expression was examined immunohistochemically in human breast tissue using a mouse anti-human fibulin-1 $\mathrm{mAb}$ (clone 3A11). The $3 \mathrm{~A} 11$ antibody reacts with an epitope located at the N-terminus of fibulin-1 and detects all four documented splice variants of the protein (Argraves et al, 1990). In normal breast tissue, fibulin-1 protein expression predominated in the ductal epithelium and underlying myoepithelium, with weaker staining evident in the loose connective tissue (L-CT) surrounding the ducts (Figure 1A). Examination of ductal carcinoma in situ (Figure 1B) and invasive breast carcinomas (Figure 1C) revealed that tumour cells expressed fibulin-1 protein, with the connective tissue surrounding these tumour cells also exhibiting moderate expression of fibulin-1.

Fibulin-1 protein expression was semiquantitatively assessed in a range of breast carcinoma and normal breast tissue biopsies by densitometric analysis of immunoblots. Purified fibulin-1 protein, derived from human placenta, was used as a positive control. Under reducing conditions, the $3 \mathrm{~A} 11 \mathrm{mAb}$ specifically recognised the $100 \mathrm{kDa}$ placenta-derived fibulin-1 protein (Figure 2A, lanes 1 and 13). In detergent extracts from breast
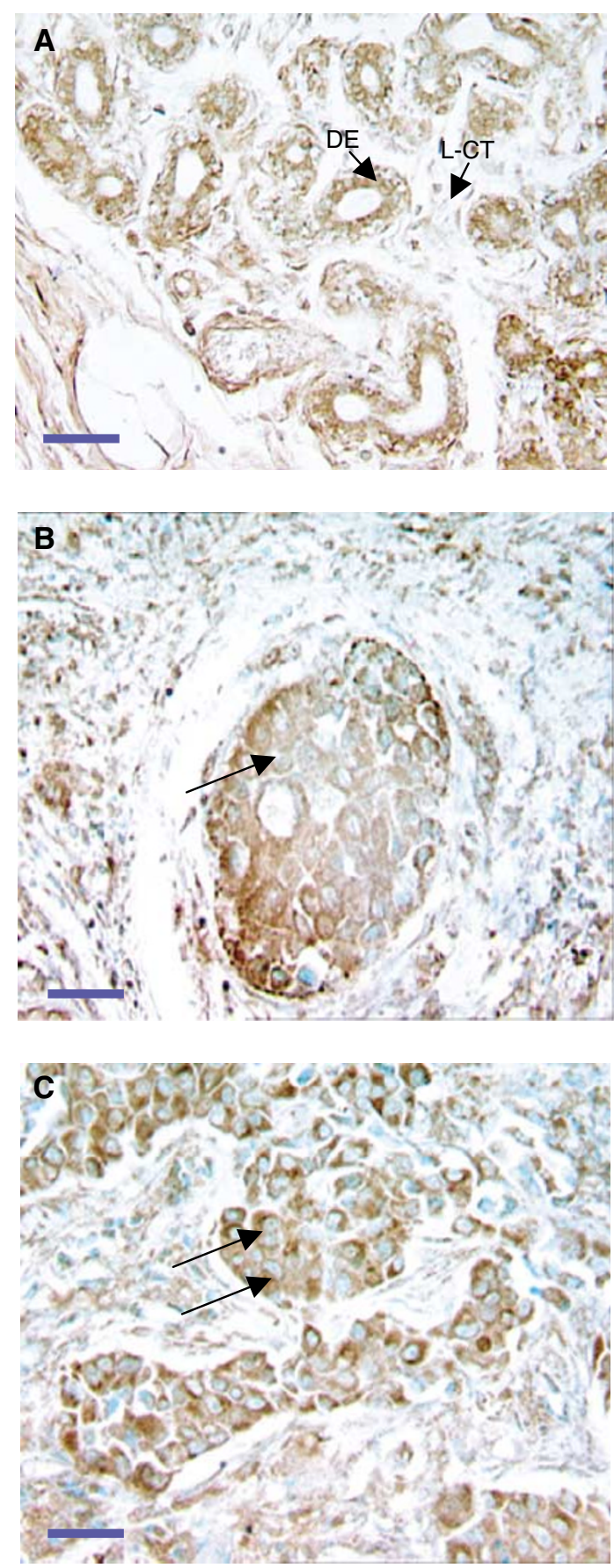

Figure I Fibulin-I protein expression in normal breast tissue and invasive ductal carcinoma. Paraffin-embedded tissue sections of normal breast tissue $(\mathbf{A})$, ductal carcinoma in situ (B) and invasive ductal carcinoma (C) were stained with antifibulin-I 3AII mAb (brown). In (A), immunostaining is prominent in the epithelial layer of the duct (DE), with weaker staining apparent within the L-CT surrounding the ducts. In (B), the carcinoma cells of solid-type ductal carcinoma in situ stained markedly with antifibulin-I antibody (arrow). In (C), fibulin-I protein expression is apparent in the invasive ductal carcinoma cells (extended arrows). Sections were counterstained with methyl green. Bars indicate $20 \mu \mathrm{m}$. Immunostaining specificity was checked using an irrelevant mouse $m A b$ of the same $\lg G$ subclass (data not shown).

tissue (Figure 2A, lanes 2-12), three major immunoreactive bands were detected, one of which corresponds to the $100 \mathrm{kDa}$ mature fibulin-1 polypeptide, with two additional bands at 55 and $50 \mathrm{kDa}$. These smaller fragments represent processed forms of fibulin-1, 


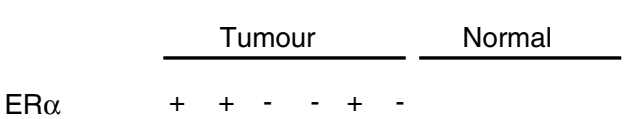

A

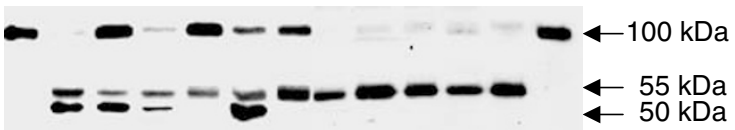

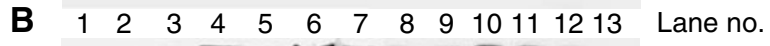
000000

Figure 2 Analysis of fibulin-I protein expression in representative breast tissue extracts. In (A), purified human fibulin-I protein (lanes I and I3) and $40 \mu \mathrm{g}$ of breast tumour extracts (lanes 2-7) and $40 \mu \mathrm{g}$ of normal breast tissue (lanes 8 - 12) extract. Samples were run on a I0\% polyacrylamide gel under reducing conditions, transferred to PVDF membrane and probed with the $3 \mathrm{Al} I \mathrm{mAb}$, which is directed against the N-terminus of human fibulin-I. In addition to the mature fibulin-I polypeptide (apparent molecular mass of $100 \mathrm{kDa}$ ) immunoreactive fragments of 55 and $50 \mathrm{kDa}$ are detectable. The ER status of the breast tumours is also indicated. In (B), the blot shown in $(\mathbf{A})$ was stripped and reprobed with a panspecific antiactin antibody to serve as a control for protein loading.

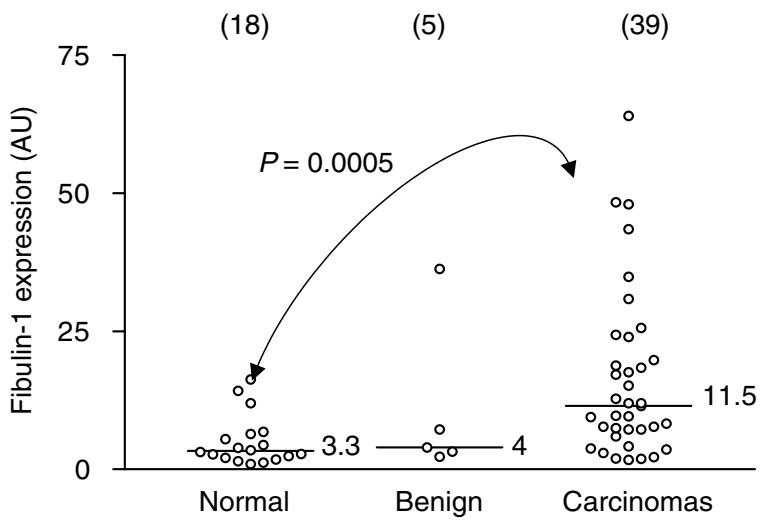

Figure 3 Comparison of full-length fibulin-I protein expression in normal breast tissues $(n=18)$, benign tumours $(n=5)$ and breast carcinomas $(n=39)$. Levels of $100 \mathrm{kDa}$ fibulin-I were quantified by densitometric analysis and expressed in arbitrary units. Bar, median value. $P$ values were determined according to the nonparametric Mann-Whitney U-test for unpaired values. Full-length fibulin-I protein was significantly elevated in the breast carcinoma specimens as compared to normal breast $(P=0.0005)$

most likely generated by proteolysis of the full-length fibulin-1 polypeptide.

A comparison of $100 \mathrm{kDa}$ fibulin-1 expression in normal breast tissue, benign tumours and breast carcinomas is shown in Figure 3. Fibulin-1 protein expression was significantly increased in breast carcinomas as compared to normal breast tissue (Mann - Whitney $U$-test, $P=0.0005)$. An increase in fibulin-1 protein expression was also observed in the breast carcinomas compared to benign tumours, but this difference did not reach significance (MannWhitney $U$-test, $P=0.2$ ), probably owing to the low number of benign tumours examined. Regarding $100 \mathrm{kDa}$ fibulin-1 expression, no significant difference was observed between normal breast tissue and benign tumours (Mann-Whitney $U$-test, $P=0.3$ ). The $55 \mathrm{kDa}$ immunoreactive fragment was equally detected in both normal and carcinoma breast tissue (Figure 2). However, the $50 \mathrm{kDa}$ fragment was found more frequently in benign breast tumours (five out of five, $100 \%)\left(\chi^{2}=4.55, P=0.03\right)$ and in breast carcinomas (35 out of $39,90 \%)\left(\chi^{2}=17.22, P<0.0001\right)$ than in normal breast tissue (six out of $18,33 \%$ ). In summary, these results provide evidence for elevated expression and altered processing of fibulin-1 protein in breast tumour development and progression.

\section{Association of fibulin-1 expression with prognostic variables}

Full-length fibulin-1 protein is known to be secreted by oestrogenresponsive ovarian cancer cells upon exposure to oestradiol (Clinton et al, 1996). In addition, fibulin-1 expression was previously shown to be inversely correlated with PR protein levels in ovarian carcinomas (Roger et al, 1998). However, expression of $100 \mathrm{kDa}$ fibulin-1 in the breast carcinomas examined here did not correlate with either ER $\alpha$ or PR status (Table 2). Previous studies have suggested benefits in viewing $E R \alpha$ and $P R$ levels as continuous rather than dichotomous variables (Chapman et al, 1996). Therefore, we examined the relation of fibulin-1 expression with $\mathrm{ER} \alpha$ and PR protein concentrations using the Spearman rank correlation test. Accordingly, fibulin-1 protein expression was inversely correlated with $\mathrm{ER} \alpha$ protein concentration ( $\mathrm{rs}=-0.34$, $P<0.04, n=36$ ), but not with $\mathrm{PR}$ levels ( $\mathrm{rs}=-0.18, P=0.3$, $n=36$ ) (Figure $5 \mathrm{~A}$ and $\mathrm{B}$ ).

When viewed as the ratio of the $50 \mathrm{kDa}$ fragment to the mature fibulin-1 polypeptide, fibulin-1 processing was more extensive in $\mathrm{ER} \alpha$-positive as compared to $\mathrm{ER} \alpha$-negative breast carcinomas $(P<0.05, n=36)$ (Figures 2 and 4$)$. A positive correlation was also found between fibulin-1 processing and absolute ER $\alpha$ protein concentration ( $\mathrm{rs}=0.49, P<0.003, n=36$ ) (Figure 5C). A similar correlation with fibulin-1 processing was observed with PR protein concentration ( $r s=0.43, P=0.008, n=36$ ) (Figure 5D). As shown in Table 2, fibulin-1 protein expression and processing did not correlate with any other prognostic variables, including tumour size, histological type, tumour stage or lymph node involvement.

\section{Fibulin-1 processing in human breast tumour-derived cells}

As processing was associated with both $\mathrm{ER} \alpha$ and $\mathrm{PR}$ in human breast carcinomas, we next studied the relation of fibulin-1 processing in vitro using three ER/PR-positive (MCF-7, T47D and BT-474) and three ER/PR-negative (MDA-MB-231, HS-578-T and SK-BR-3) human breast tumour-derived cell lines. Immunoblot analysis of fibulin-1 was performed on both cell extracts and CCM (Figure 6). Full-length fibulin-1 protein was detected in the CCM (Figure 6A), but not in the cell extract (Figure 6B) of the six human breast tumour-derived cell lines analysed. The $50 \mathrm{kDa}$ fragment was detected at different levels in the various cell extracts examined, with lower amounts being expressed in two ER/PRnegative breast cancer cell lines (MDA-MB-231 and HS-578-T). An additional $26 \mathrm{kDa}$ fragment was detected in the three ER/PRpositive cell lines (Figure $6 \mathrm{~B}$ ). The $26 \mathrm{kDa}$ fragment was also detected in two out of $36(5.5 \%)$ of the breast carcinomas (data not shown). Notably, this subset of carcinomas expressed strikingly high levels of both $\mathrm{ER} \alpha$ and PR. The $50 \mathrm{kDa}$ fragment may represent an intermediate product, which can be further processed into a $26 \mathrm{kDa}$ fragment. Alternatively, the $26 \mathrm{kDa}$ fragment may be directly derived from the mature $100 \mathrm{kDa}$ fibulin-1 polypeptide via degradation. The absence of the $55 \mathrm{kDa}$ fragment in any of the breast tumour cell lines examined may be reflective of a stromal origin for this fragment in breast tissue. Overall, fibulin-1 processing was more extensive in the ER/PR-positive as compared to ER/PR-negative breast tumour cell lines.

\section{Fibulin-1 processing is not regulated by oestrogen in T47D breast tumour cells}

We then examined the effect of oestrogen on fibulin-1 processing in the ER/PR-positive T47D cell line. Cells were deprived of steroids by culturing for 5 days in 10\% DCC-FCS phenol red-free DMEM. Both the rate of cell proliferation and levels of oestrogeninducible proteins, such as the PR, are significantly reduced when the cells are cultured in serum pretreated with dextran charcoal (Hurd et al, 1999; Iwasaki et al, 1999). The charcoal treatment is 
Table 2 Relationship between prognostic variables and fibulin-। expression and processing

\begin{tabular}{|c|c|c|c|c|c|}
\hline Clinical characteristics & $n^{\mathbf{a}}$ & Fibulin-I expression ${ }^{b}$ & $P^{c}$ & Fibulin-I processing ${ }^{d}$ & $p^{\mathbf{e}}$ \\
\hline \multicolumn{6}{|l|}{ Tumour size } \\
\hline$\leqslant 2 \mathrm{~cm}$ & 6 & 15 & & 19.9 & \\
\hline$>2 \mathrm{~cm}$ & 30 & 19.2 & 0.4 & 18.2 & 0.7 \\
\hline Unknown & 3 & & & & \\
\hline \multicolumn{6}{|l|}{ Histological type } \\
\hline Ductal & 27 & 16.5 & & 17.6 & \\
\hline $\begin{array}{l}\text { Lobular } \\
\text { Unknown }\end{array}$ & $\begin{array}{l}7 \\
5\end{array}$ & 21.3 & 0.3 & 17.1 & 0.9 \\
\hline \multirow{2}{*}{\multicolumn{6}{|c|}{ Histological grading }} \\
\hline & & & & & \\
\hline GI,G2 & 12 & 16.8 & & 13.3 & \\
\hline $\begin{array}{l}\text { G3 } \\
\text { Unknown }\end{array}$ & $\begin{array}{r}20 \\
7\end{array}$ & 16.3 & 0.9 & 18.4 & 0.1 \\
\hline \multicolumn{6}{|l|}{ Nodal status } \\
\hline Negative & 7 & 19.3 & & 12.7 & \\
\hline $\begin{array}{l}\text { Positive } \\
\text { Unknown }\end{array}$ & $\begin{array}{l}20 \\
12\end{array}$ & 16.4 & 0.5 & 18.7 & 0.2 \\
\hline \multicolumn{6}{|l|}{$E R \alpha$ status $^{f}$} \\
\hline Positive & 20 & 15.9 & & 21.7 & \\
\hline Negative & 16 & 21.8 & 0.09 & 14.6 & 0.045 \\
\hline Unknown & 3 & & & & \\
\hline \multicolumn{6}{|l|}{ PR status ${ }^{g}$} \\
\hline Positive & 15 & 16.9 & & 21.6 & \\
\hline Negative & 21 & 19.6 & 0.4 & 16.6 & 0.2 \\
\hline Unknown & 3 & & & & \\
\hline
\end{tabular}

${ }^{a} n$, number of breast carcinomas including 36 primary breast carcinomas and three lymph node metastases. ' ${ }^{b}$ eve of full-length ( $100 \mathrm{kDa}$ ) fibulin-I polypeptide as determined by densitometric analyses of immunoblots (represented in arbitrary units). ${ }^{c, e} P$-values were calculated using a nonparametric Mann-Whitney U-test for comparison of means. 'Fibulin-I processing was determined as the ratio of the $50 \mathrm{kDa}$ fragment to the mature form (i.e. 50/ $100 \mathrm{kDa}$ ). ${ }^{\mathrm{f}} \mathrm{ER} \alpha=$ oestrogen receptor alpha. ${ }^{\mathrm{g}} \mathrm{PR}=$ progesterone receptor.

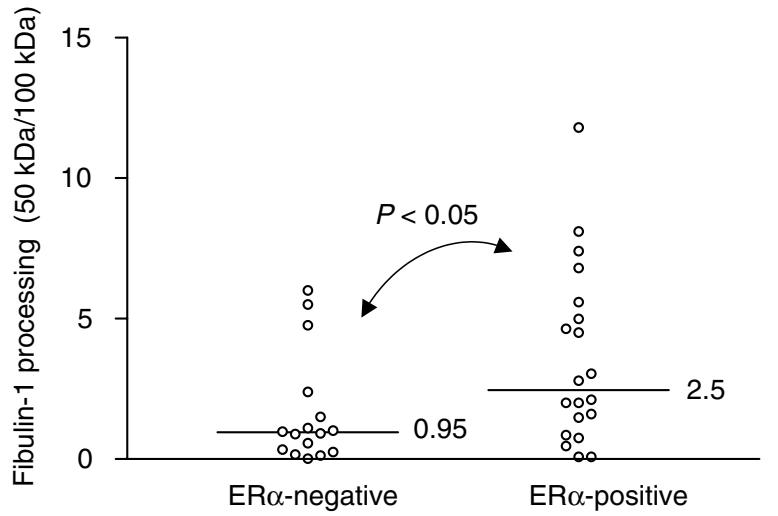

Figure 4 Relationship between fibulin-I processing and ER status. Levels of $100 \mathrm{kDa}$ fibulin-I and the $50 \mathrm{kDa}$ processed fragment were quantified by densitometric analysis of immunoblots. The resulting arbitrary units were used to determine the extent of fibulin-I processing (expressed as the ratio of the $50 \mathrm{kDa}$ fragment to the full-length polypeptide). Bar, median value. $P$ values were determined according to the nonparametric Mann-Whitney $U$-test for unpaired values. The extent of fibulin-I processing $(50 / 100 \mathrm{kDa})$ was significantly higher in ER $\alpha$-positive than in ER $\alpha$-negative breast carcinomas $(P<0.05)$.

98\% effective in removing oestradiol (Devleeschouwer et al, 1987). As shown in Figure 7B, the level of PR is significantly reduced when the cells are grown for 5 days in stripped serum (lane 3; C stripped) compared with cells grown in control whole serum (lane 2; C whole). Exposure of the cells to $10 \mathrm{~nm}$ oestradiol for $48 \mathrm{~h}$ reverses this effect (lane 4), indicating reactivation of the ER pathway. However, alteration in ER function via either steroid depletion or re-exposure to oestrogen did not affect fibulin-1 processing (Figure 7A). Similarly, the level of fibulin-1 secreted into the medium from T47D cells was not altered in response to oestrogen stimulation (Figure 8).

\section{DISCUSSION}

The present investigation demonstrates that elevated fibulin-1 protein expression is associated with breast cancer. This work is in agreement with a recent study showing increased expression of fibulin-1 mRNA in a small panel of breast carcinoma specimens as compared to normal breast tissue (Forti et al, 2002). In our study, fibulin-1 protein was detected via immunhistochemistry in both the stromal and epithelial compartments of normal and neoplastic breast tissue. In addition, we observed no significant alteration in the expression of the $55 \mathrm{kDa}$ processed form of fibulin-1 between normal- and tumour-derived breast tissue. Thus, it is unlikely that the increase in the expression of full-length fibulin-1 protein in breast carcinoma is due primarily to an increase in the ratio of epithelial cells. This issue may be resolved in future studies examining the expression of fibulin-1 in specific cellular compartments isolated by microdissection. In the case of ovarian cancer, while fibulin-1 mRNA is produced by tumour-derived epithelial cells, fibulin-1 protein has been shown to accumulate in stroma surrounding the tumour cells (Roger et al, 1998). Given that the same mAb was used in both studies, it may be concluded that fibulin-1 protein accumulates in different compartments in a context-specific manner.

A number of other ECM proteins display modulated expression in association with cancer. For example, fibronectin and tenascin 

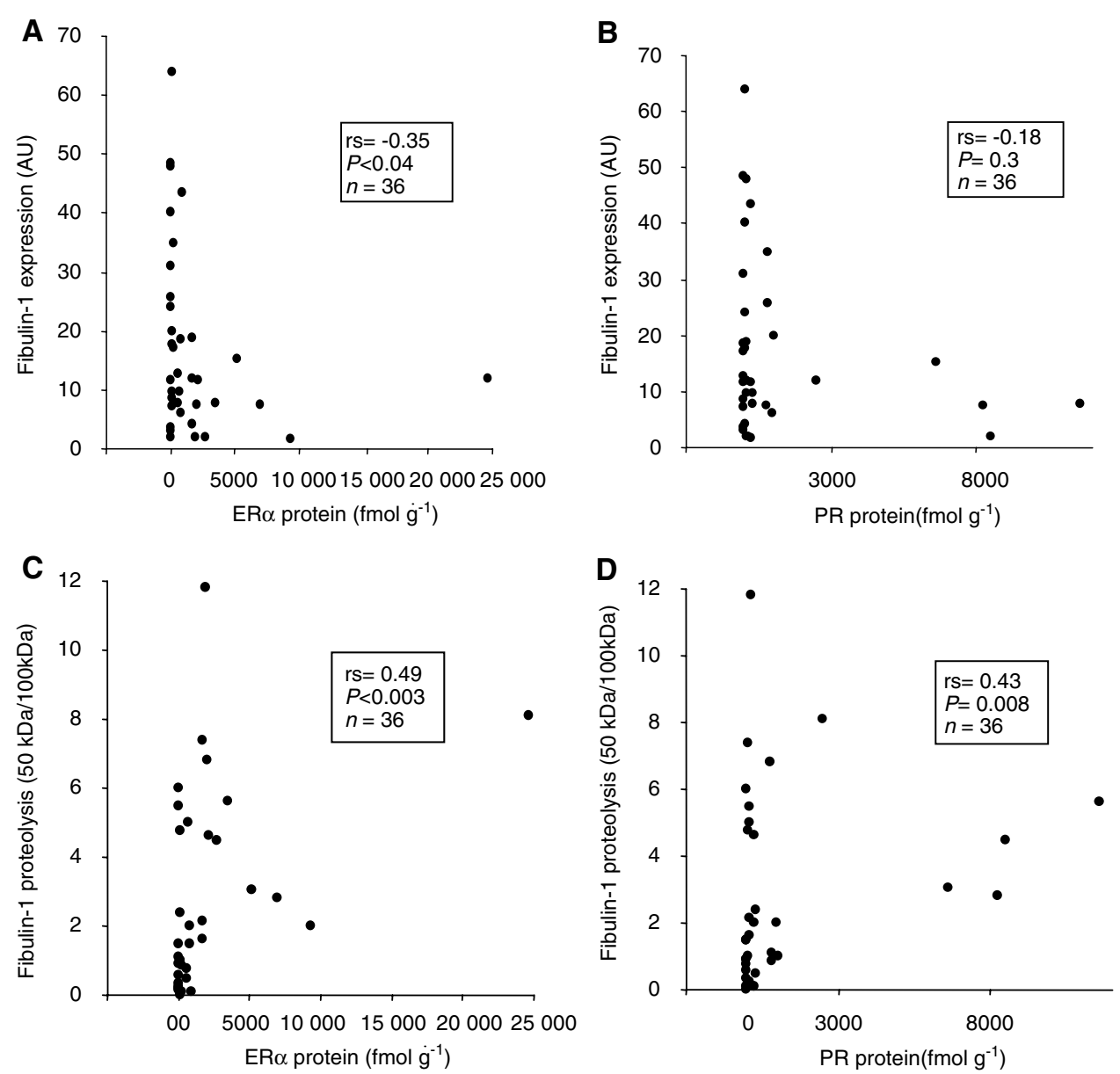

Figure 5 Relationship between fibulin-I expression $(\mathbf{A}, \mathbf{B})$ or processing $(\mathbf{C}, \mathbf{D})$ and $E R \alpha(\mathbf{A}, \mathbf{C})$ and PR $(\mathbf{B}, \mathbf{D})$ protein concentration. Fibulin- I expression and processing was determined as in Figures 3 and 4, respectively. The ER $\alpha$ and PR concentrations were determined by cytosolic assays. There was a significant inverse correlation between fibulin-I expression and ER $\alpha$ protein concentration ( $r s=-0.34, P<0.04, n=36$; the Spearman rank correlation). In addition, the correlation between fibulin-I processing and $E R \alpha(r s=0.49, P<0.003)$ and PR receptor $(r s=0.43, P<0.008)$ status was highly significant.

are upregulated in breast cancer (Mackie et al, 1987; Loridon-Rosa et al, 1988; Koukoulis et al, 1993; Ishihara et al, 1995; Takei et al, 1995, 1998; Jahkola et al, 1996), while laminin-5 expression is increased in gliomas, gastic carcinomas, and squamous carcinomas, but downregulated in prostate and breast carcinomas (Martin et al, 1988). At least one common denominator between these proteins is that they each influence cell adhesion and migration (Akiyama et al, 1995; Giese et al, 1996; Romberger, 1997; Greenwood and Murphy-Ullrich, 1998; Hirosaki et al, 2000; Twal et al, 2001). Fibulin-1 has been shown to suppress the adhesion and motility of a number of tumour cell lines, including the breast carcinoma cell line MDA-MB-231. The elevated expression of fibulin-1 protein seen in breast and ovarian carcinomas (Clinton et al, 1996) may be reflective of a similar role in vivo. The recent observation that ovarian carcinomas exhibit an increased ratio of fibulin-1C:1D mRNA (Moll et al, 2002) suggests that these fibulin1 variants exhibit differing functions. It is tempting to propose that the balance of fibulin-1 variant expression is an important determinant of whether the expressed fibulin-1 displays tumoursuppressive or oncogenic activities.

In addition to elevated expression of the full-length $(100 \mathrm{kDa})$ fibulin-1 polypeptide in breast carcinomas $v s$ normal breast tissue, we also observed differential production of additional fibulin-1 immunoreactive fragments. The exact origin of these $\mathrm{N}$-terminal fragments is still unclear, but the most likely mechanism of generation is via proteolysis of the mature fibulin-1 polypeptide.
Indeed, fibulin-1 proteolysis has already been described in vitro (Sasaki et al, 1996) and in studies of cultured skin fibroblastic cells (Debeer et al, 2002), as well as in the skin of mice exhibiting 2,4-dinitrofluorobenzene-induced chronic contact dermatitis (Kusubata et al, 1999). Other explanations for the origin of the $\mathrm{N}$-terminal fibulin-1 fragments include differential alternative splicing and/or the usage of internal ribosome entry sites.

In this study, we indicate that altered fibulin-1 processing is associated with breast cancer. Specifically, a $50 \mathrm{kDa}$ N-terminal fragment of fibulin-1 was detected more frequently in breast carcinomas as compared to normal breast tissue. Moreover, an increased ratio of the $50 \mathrm{kDa}$ fragment to the mature fibulin-1 polypeptide was observed in $\mathrm{ER} \alpha$-positive breast carcinomas as compared to ER $\alpha$-negative carcinomas. Assuming that the observed immunoreactive polypeptides correspond to proteolytic fragments of fibulin-1, our results indicate that altered proteolysis of fibulin-1 is also associated with breast cancer. The $55 \mathrm{kDa}$ fragment of fibulin-1 detected in both normal and breast cancer tissues may represent a precursor form, which is further digested to the $50 \mathrm{kDa}$ fragment. On the other hand, it may represent a phosphorylated version of the $50 \mathrm{kDa}$ fragment.

Additionally, the $26 \mathrm{kDa}$ fragment was only detectable in ER $\alpha$ positive breast carcinomas and ER $\alpha$-positive breast cancerderived cell lines. Digestion of mouse fibulin-1 protein with human leukocyte elastase produces an $\mathrm{N}$-terminal fragment of 


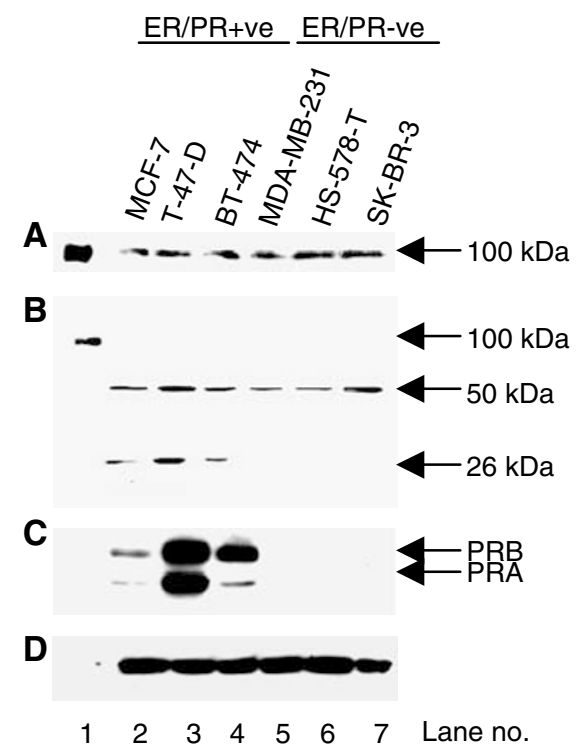

Figure 6 Fibulin-I expression and processing in ER/PR-positive and ER/ PR-negative human breast tumour-derived cell lines. In (A) and (B), aliquots of concentrated CCM and detergent extracts of the cells, respectively, were immunoblotted using antifibulin-I mAb. In (C), blot $B$ was stripped and reprobed with an anti-PR mAb that detects two isoforms of the PR protein, PRB $(120 \mathrm{kDa})$ and PRA $(94 \mathrm{kDa})$. Only the ER/PRpositive cell lines expressed detectable levels of PR protein. In (D), blot $B$ was again stripped and reprobed with the antiactin $\mathrm{mAb}$.

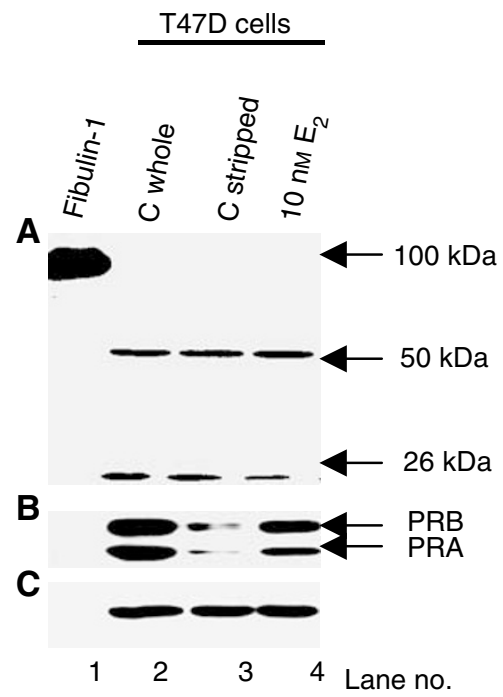

Figure 7 Western blot analysis of the effect of oestradiol $\left(E_{2}\right)$ on fibulinI processing. Purified fibulin-I protein (lane I) and aliquots of detergent extracts from T47D cells grown in either endogenous steroid-containing serum-free medium (lane 2; C whole), steroid-depleted serum-free medium containing ethanol vehicle (lane 3; C stripped) or steroid-depleted serum-free medium containing $10 \mathrm{nM}$ exogenous $\mathrm{E}_{2}$ (lane 4) were immunoblotted using antifibulin-I $3 \mathrm{~A} I \mathrm{I} \mathrm{mAb}(\mathbf{A})$, anti-PR $\mathrm{mAb}(\mathbf{B})$, and antiactin $\mathrm{mAb}(\mathbf{C})$. See Materials and Methods for details of culture conditions. Blots are representative of three independent experiments.

\section{REFERENCES}

Akiyama SK, Olden K, Yamada KM (1995) Fibronectin and integrins in invasion and metastasis. Cancer Metastasis Rev 14: $173-189$

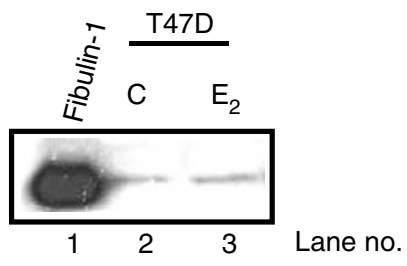

Figure 8 Western blot analysis of the effect of oestradiol $\left(E_{2}\right)$ on fibulinI expression. Purified fibulin-I protein (lane I) and aliquots of concentrated CCM $(10 \mathrm{ml}$ original volume) from either steroid-depleted serum-free medium containing ethanol vehicle (lane 2) or steroid-depleted serum-free medium containing $10 \mathrm{nM}$ exogenous $\mathrm{E}_{2}$ (lane 3 ) were immunoblotted using antifibulin-I 3AII mAb. See Materials and Methods for details of culture conditions. Blot is representative of three independent experiments.

approximately $26 \mathrm{kDa}$ (Sasaki et al, 1996), which may correspond to the immunoreactive fragment observed in this study. Intriguingly, elastases are also elevated in breast cancer (Kao and Stern, 1986). Furthermore, proteinase-like peptidase activities were previously found to be higher in patients with steroid receptorrich breast tumours than in receptor-poor tumours (Vasishta et al, 1989). If the observed fragments are derived by proteolysis of mature fibulin-1 polypeptide, it is reasonable to hypothesise that the altered processing of fibulin-1 is reflective of differential proteinase activity in the breast tumours.

Fibulin-1C mRNA expression can be induced by oestrogen in ER $\alpha$-positive ovarian tumour cell lines (Clinton et al, 1996); however, its association with $\mathrm{ER} \alpha$ status in ovarian cancers is still unclear (Clinton et al, 1996; Moll et al, 2002). Interestingly, we found an inverse relation between the levels of full-length fibulin-1 protein and $\mathrm{ER} \alpha$ protein concentration in breast cancers. We also found no evidence for augmented secretion of fibulin-1 by ER $\alpha$ positive T47D breast cancer cells treated with oestrogen. While fibulin-1C and -1D variants differ at the C-terminus, both yield similar sized mature polypeptides as determined by immunoblot analysis. Indeed, currently available antibodies are still not capable of determining which fibulin-1 variant is predominantly expressed. It remains to be seen as to whether hormonal regulation of fibulin1 expression is variant-specific.

In conclusion, our results have shown that fibulin-1 protein is elevated in human breast carcinomas as compared to normal breast tissue. Upregulation of fibulin-1 protein may be useful as a marker for breast and ovarian cancer. Clearly, additional investigations are required to determine if enhanced fibulin-1 protein expression is associated with other tumour types and if such altered expression is variant-specific. Also, further analysis will be required to determine if the processed fragments of fibulin1 retain biological activity.

\section{ACKNOWLEDGEMENTS}

We thank Drs Norma O' Donovan, Deirdre Foley and Theresa Maguire for their technical assistance. This work is supported by grants from The Irish Cancer Society, Enterprise Ireland, European Commission, the Association for International Cancer Research (WMG) and NIH Grant HL52813 (WSA). LMG is supported by a $\mathrm{PhD}$ Studentship from Cancer Research Ireland, formerly the Irish Cancer Society.
Argraves WS, Tran H, Burgess WH, Dickerson K (1990) Fibulin is an extracellular matrix and plasma glycoprotein with repeated domain structure. J Cell Biol 111: 3155-3164 
Balbona K, Tran H, Godyna S, Ingham KC, Strickland DK, Argraves WS (1992) Fibulin binds to itself and to the carboxyl-terminal heparinbinding region of fibronectin. J Biol Chem 267: $20120-20125$

Chapman JW, Mobbs BG, McCready DR, Lickley HL, Trudeau ME, Hanna W, Kahn HJ, Sawka CA, Fish EB, Pritchard KI (1996) An investigation of cut-points for primary breast cancer oestrogen and progesterone receptor assays. J Steroid Biochem Mol Biol 57: 323 - 328

Clinton GM, Rougeot C, Derancourt J, Roger P, Defrenne A, Godyna S, Argraves WS, Rochefort H (1996) Estrogens increase the expression of fibulin-1, an extracellular matrix protein secreted by human ovarian cancer cells. Proc Natl Acad Sci USA 93: 316-320

Cullen R, Maguire TM, McDermott EW, Hill AD, O'Higgins NJ, Duffy MJ (2001) Studies on oestrogen receptor-alpha and -beta mRNA in breast cancer. Eur J Cancer 37: 1118-1122

Debeer P, Schoenmakers EF, Twal WO, Argraves WS, De Smet L, Fryns JP, Van De Ven WJ (2002) The fibulin-1 gene (FBLN1) is disrupted in a $\mathrm{t}(12 ; 22)$ associated with a complex type of synpolydactyly. J Med Genet 39: $98-104$

Devleeschouwer N, Legros N, Olea-Serrano N, Paridaens R, Leclercq G (1987) Estrogen conjugates and serum factors mediating the estrogenic trophic effect on MCF-7 cell growth. Cancer Res 47: 5883-5887

Forti S, Scanlan MJ, Invernizzi A, Castiglioni F, Pupa S, Agresti R, Fontanelli R, Morelli D, Old LJ, Pupa SM, Menard S (2002) Identification of breast cancer-restricted antigens by antibody screening of SKBR3 cDNA library using a preselected patient's serum. Breast Cancer Res Treat 73: $245-256$

Giese A, Loo MA, Norman SA, Treasurywala S, Berens ME (1996) Contrasting migratory response of astrocytoma cells to tenascin mediated by different integrins. J Cell Sci 109: 2161-2168

Greenwood JA, Murphy-Ullrich JE (1998) Signaling of de-adhesion in cellular regulation and motility. Microsc Res Technol 43: 420-432

Hayashido Y, Lucas A, Rougeot C, Godyna S, Argraves WS, Rochefort H (1998) Estradiol and fibulin-1 inhibit motility of human ovarian- and breast-cancer cells induced by fibronectin. Int J Cancer 75: 654-658

Hirosaki T, Mizushima H, Tsubota Y, Moriyama K, Miyazaki K (2000) Structural requirement of carboxyl-terminal globular domains of laminin alpha 3 chain for promotion of rapid cell adhesion and migration by laminin-5. J Biol Chem 275: $22495-22502$

Hurd C, Nag K, Khattree N, Alban P, Dinda S, Moudgil VK (1999) Agonist and antagonist-induced qualitative and quantitative alterations of progesterone receptor from breast cancer cells. Mol Cell Biochem 199: $49-56$

Ishihara A, Yoshida T, Tamaki H, Sakakura T (1995) Tenascin expression in cancer cells and stroma of human breast cancer and its prognostic significance. Clin Cancer Res 1: 1035-1041

Iwasaki K, Underwood B, Herman M, Dinda S, Kodali S, Kloosterboer HJ, Hurd C, Moudgil VK (1999) Effects of antiprogestins on the rate of proliferation of breast cancer cells. Mol Cell Biochem 198: $141-149$

Jahkola T, Toivonen T, von Smitten K, Blomqvist C, Virtanen I (1996) Expression of tenascin in invasion border of early breast cancer correlates with higher risk of distant metastasis. Int J Cancer 69: 445 - 447
Kao RT, Stern R (1986) Elastases in human breast carcinoma cell lines. Cancer Res 46: 1355-1358

Koukoulis GK, Howeedy AA, Korhonen M, Virtanen I, Gould VE (1993) Distribution of tenascin, cellular fibronectins and integrins in the normal, hyperplastic and neoplastic breast. J Submicrosc Cytol Pathol 25: $285-295$

Kusubata M, Hirota A, Ebihara T, Kuwaba K, Matsubara Y, Sasaki T, Kusakabe M, Tsukada T, Irie S, Koyama Y (1999) Spatiotemporal changes of fibronectin, tenascin-C, fibulin-1, and fibulin-2 in the skin during the development of chronic contact dermatitis. J Invest Dermatol 113: $906-912$

Loridon-Rosa B, Vielh P, Cuadrado C, Burtin P (1988) Comparative distribution of fibronectin and vitronectin in human breast and colon carcinomas. An immunofluorescence study. Am J Clin Pathol 90: 7-16

Mackie EJ, Chiquet-Ehrismann R, Pearson CA, Inaguma Y, Taya K, Kawarada Y, Sakakura T (1987) Tenascin is a stromal marker for epithelial malignancy in the mammary gland. Proc Natl Acad Sci USA 84: $4621-4625$

Martin KJ, Kwan CP, Nagasaki K, Zhang X, O'Hare MJ, Kaelin CM, Burgeson RE, Pardee AB, Sager R (1988) Down-regulation of laminin-5 in breast carcinoma cells. Mol Med 4: 602-613

Moll F, Katsaros D, Lazennec G, Hellio N, Roger P, Giacalone PL, Chalbos D, Maudelonde T, Rochefort H, Pujol P (2002) Estrogen induction and overexpression of fibulin-1C mRNA in ovarian cancer cells. Oncogene 21: $1097-1107$

Qing J, Maher VM, Tran H, Argraves WS, Dunstan RW, McCormick JJ (1997) Suppression of anchorage-independent growth and matrigel invasion and delayed tumor formation by elevated expression of fibulin$1 \mathrm{D}$ in human fibrosarcoma-derived cell lines. Oncogene 15: 2159-2168

Roger P, Pujol P, Lucas A, Baldet P, Rochefort H (1998) Increased immunostaining of fibulin-1, an estrogen-regulated protein in the stroma of human ovarian epithelial tumors. Am J Pathol 153: 1579-1588

Romberger DJ (1997) Fibronectin. Int J Biochem Cell Biol 29: 939-943

Sasaki T, Mann K, Murphy G, Chu ML, Timpl R (1996) Different susceptibilities of fibulin-1 and fibulin-2 to cleavage by matrix metalloproteinases and other tissue proteases. Eur J Pathol 240: 427-434

Takei H, Iino Y, Horiguchi J, Yokoe T (1995) Immunohistochemical fibronectin staining pattern and prognosis in invasive breast carcinoma. Oncology 52: 106-111

Takei H, Iino Y, Horiguchi J, Maemura M, Koibuchi Y, Nagaoka H, Yokoe T, Oyama T, Morishita Y (1998) Angiogenesis and stromal fibronectin expression in invasive breast carcinoma. Int J Oncol 12: 517-523

Tran H, Mattei M, Godyna S, Argraves WS (1997) Human fibulin-1D: molecular cloning, expression and similarity with S1-5 protein, a new member of the fibulin gene family. Matrix Biol 15: 479-493

Twal WO, Czirok A, Hegedus B, Knaak C, Chintalapudi MR, Okagawa H, Sugi Y, Argraves WS (2001) Fibulin-1 suppression of fibronectinregulated cell adhesion and motility. J Cell Sci 114: 4587-4598

Vasishta A, Baker PR, Preece PE, Wood RA, Cuschieri A (1989) Proteinaselike peptidase activities and oestrogen receptor levels in breast cancer tissue. J Cancer Res Clin Oncol 115: 89-92 